\title{
Technical Computation of Animal Diet Formulation: A Review
}

\author{
Pratiksha Saxena* and Neha Khanna \\ Department of Applied Mathematics, Gautam Buddha University, India
}

Submission: August 26, 2017; Published: September 27, 2017

*Corresponding author: Pratiksha Saxena, Department of Applied Mathematics, Gautam Buddha University, Greater Noida, India, Email: pratiksha@gmail.com

\section{Introduction}

This article provides the general understanding of the computer programs, excel spreadsheets and software used for the livestock feed mix formulation. Various computer programs, excel spreadsheets and software have been developed for formulating optimal livestock diet. Most of the programs and software, developed for the formulation of livestock diet are based on linear programming technique which provides least cost diet formulation. Some of the programs are formulating animal diet on the basis of combination of two or more mathematical programming techniques.

\section{Abbreviations}

PRP: Profession Ration Package

\section{Computer Programs}

Jones etal. [1] developed a research program for computerized feeding management system for field service program. This was a multi-stage project for the Southern US states and its acceptance was evaluated by other states. It represents the feasibility of approaching dairy cattle nutrition from a cooperative multistage effort and works on a large database. The system is now available to dairymen for the formulation of feeding guidelines by the Dairy Herd Improvement Association.

In Roush et al. [2] developed a stochastic-linear program Excel workbook that consisted of two worksheets illustrating linear and stochastic program approaches. Both approaches used the Excel Solver addin. A published linear program problem served as an example for the ingredients, nutrients and costs as a benchmark in the development of the linear and stochastic programs. The Excel spreadsheet was set up to calculate MOS value. According to the requested probability, it was same for both of the linear and stochastic programs. Spreadsheet results illustrated the flexibility, accuracy and precision of the stochastic program over the linear program in meeting the requested nutrient probability.

\section{Spreadsheets and Tools}

In Kavcic [3] constructed a user-friendly tool for beef farmers in an Excel framework in which mathematical deterministic programming techniques have been used. A linear program along with a weighted goal program was used, which results in more efficient beef ration formulation. The user could choose different objectives, such as, to minimize forage costs, to achieve more balanced ration or to implement own weights. This tool was applicable for practical decision making on beef farms, enabling cost-effective and nutrient-balanced beef production.

In Zgajnar et al. [4] developed a spreadsheet tool for the formulation of a daily cow ration. The MS Excel platform has been used to develop two linked sub models. It merged the common LP model and the WGP model with a penalty function. The first sub model was included in the tool to make an estimate of the least-cost magnitude. The obtained result was entered into the second sub model as the goal which should be met as closely as possible. The tool was tested at two different values of preferential weights for dairy cows with a $25 \mathrm{~kg}$ daily milk yield. In contrast to the common linear program tools, which terminate at formulation of the least-cost ration, this tool provided more efficient rations (in both economic and nutritive terms) by finetuning of the nutritive goals and by allowing harmless deviations from these goals by applying penalty functions.

Zgajnar et al. [5] presented a tool based on a threestage optimization approach presented for pigs' daily ration formulation. In the first stage, a common linear program is used to formulate rations on a least-cost basis. In the second stage, a sub model, based on WGP and penalty functions, is used to formulate a nutritionally balanced and economically acceptable ration. The ration cost is calculated in the first phase. In the last stage, the tool runs the first and the second phases several times with the intent of finding the most efficient energy content of the ration. This model enables decision makers to find the optimal 
energy con-tent of the pigs' feed, which changes frequently owing to rapidly fluctuating economic circumstances.

Zgajnar et al. [5] developed a tool based on a three-step approach. In the first step, a common linear program was utilized to formulate least-cost ration. In the second step, a sub-model based on WGP is developed which was supported by a system of penalty functions. This approach is very much similar as that of Zgajnar et al. [4].

\section{Software}

In Weaver et al. [6,7] evaluated a method for selecting dairy ration formulation software for microcomputers. Data were collected from a survey of practicing nutritionists and software programmers. A benchmark problem consisting of 15 activities required in designing dairy rations was chosen to evaluate ease of use, ease of learning and software performance. A list of features and a benchmark problem have been developed for evaluation of dairy nutrition software. Features included documentation, user interface characteristics, setup features, input and output variables, and flexibility to specify the objective function. This feature list can be used to determine whether a users requirements will be met by specific software. The benchmark can provide a tool for quantitatively comparing the ease with which nutrition software can be learned and used.

In addition, the benchmark can provide a controlled environment to evaluate and compare ration formulation results. The features list and benchmark have demonstrated the strengths and weaknesses of Mixit 2+, Noah and Profession
Ration Package (PRP) in this comparison. Comparison of these three programs was illustrated the diversity of features, user friendliness and performance among programs designed for a similar application.

BEST MIX is a commercially available feed formulation software used for achieving the optimal livestock diet at least cost with the satisfaction of all nutritional requirements. It also enables the user to control the production parameters. It's a profit driven feed formulation software. Its results can be directly translated into practical products. Feed formulation is software which helps in obtaining the least cost feed. It has two functions: formulating the least cost feed mix and analysis of the formula. Feed Formulation uses linear programming to find least cost feed mix. Trial and Error method has been used for formula analysis. Eco-Mix is also a least cost feed formulation software.

It is suitable for finding least cost feed mix for any kind of livestock. In this software, unlimited number of feed ingredients and nutrients can be incorporated for feed mix formulation. The minimum and maximum values of feed ingredients and nutrients can also be changed easily. Win Feed is the only software which works on linear as well as stochastic programming techniques and provides least cost feed mix. It can provide least cost feed mix for ruminants as well as non-ruminants. It has the power to handle unlimited number of feed ingredients and nutrients. It has an easy system to handle the database of the composition of the feed ingredients. User also has the facility to import or export data from Excel Table 1.

Table 1:

\begin{tabular}{|c|c|c|c|c|c|c|}
\hline $\begin{array}{c}\text { Software } \\
\text { name }\end{array}$ & Operating System & Least Cost & $\begin{array}{c}\text { Nutrient } \\
\text { variability }\end{array}$ & $\begin{array}{c}\text { Multiple } \\
\text { objectives }\end{array}$ & $\begin{array}{c}\text { Formula } \\
\text { Analysis }\end{array}$ \\
\hline BESTMIX & Windows & Yes & No & No & All & No \\
\hline $\begin{array}{c}\text { Feed } \\
\text { Formulation }\end{array}$ & $\begin{array}{c}\text { Windows XP with SP2/ Windows } \\
2000 \text { with SP4 / Windows Server } \\
2003 \text { with SP1/ Windows Vista }\end{array}$ & Yes & No & No & $\begin{array}{c}\text { Layers, Broilers, Sheep, } \\
\text { Pigs, Fish, etc. }\end{array}$ & Yes \\
\hline Eco-Mix & Windows & Yes & No & No & All & Yes \\
\hline Winfeed & $\begin{array}{c}\text { Windows NT, 98, Me, 2000, XP } \\
\text { and Windows 2003 }\end{array}$ & Yes & Yes & No & $\begin{array}{c}\text { poultry, cattle, sheep, } \\
\text { horses, dogs, cats, fish } \\
\text { and other aqua culture } \\
\text { etc. }\end{array}$ & Yes \\
\hline
\end{tabular}

\section{References}

1. Jones GM, Chandler PT, Murley WR, Brown CA, Walker HW (1980) Implementation of a regional ration formulation program for the South eastern states. Journal of Dairy Science 63: 856-864.

2. Roush WB, Purswell J, Branton SL (2007) An adjustable nutrient margin of safety comparison using linear and stochastic programming in an excel spreadsheet. Journal of Applied Poultry Research 16: 514520 .

3. Zgajnar J, Kavcic S (2008) Spread sheet tool for least-cost and nutrition balanced beef ration formulation. Acta Agriculture Slovenica 2: 187-94.

4. Zgajnar J, Juvancic L, Kavcic S (2009) Combination of linear and weighted goal programming with penalty function in optimisation of a daily dairy cow ration. Agricultural Economics Czech 55(10): 492-500.

5. Zgajnar J, Kavcic S, Ljubljana, Slovenia (2009) Three phase feed mix optimization for growing pigs. $17^{\text {th }}$ International Farm Management Congress, Bloomington/Normal, lllinois, USA.

6. Weaver LD, Olivas MA, Gall JC (1988) Identifying features, performance, and limitations of dairy ration formulation software a comparison of three ration formulation programs. Journal of Dairy Science 71(4): 1104-1115.

7. Zgajnar J, Kavcic S (2008) Optimization of bulls fattening ration applying mathematical deterministic programming approach. Bulgarian Journal of Agricultural Science 14(1): 76-86. 
This work is licensed under Creative

Commons Attribution 4.0 Licens

DOI: $10.19080 /$ JDVS.2017.04.555626
Your next submission with Juniper Publishers will reach you the below assets

- Quality Editorial service

- Swift Peer Review

- Reprints availability

- E-prints ServiceManuscript Podcast for convenient understanding

- Global attainment for your research

- Manuscript accessibility in different formats

( Pdf, E-pub, Full Text, Audio)

- Unceasing customer service

Track the below URL for one-step submission https://juniperpublishers.com/online-submission.php 